\title{
THE EFFECTS OF FEEDBACK ON COOPERATION IN THE PRISONER'S DILEMMA GAME SIMULATING A CLOSED MARKET SCENARIO
}

\section{EFEITOS DO FEEDBACK SOBRE A COOPERAÇÃO NO JOGO DO DILEMA DO PRISIONEIRO SIMULANDO UM CENÁRIO DE MERCADO FECHADO}

\author{
MARCO TAGLIABUE - ORCID 0000-0002-2438-6943 \\ INGUNN SANDAKER - ORCID 0000-0001-9942-3027 \\ GUNNAR REE - ORCID 0000-0002-9245-4290 \\ Oslomet - Oslo Metropolitan University, Oslo, Norway
}

\begin{abstract}
RESUMO
Esse estudo explora os efeitos do feedback sobre a cooperação no Dilema do Prisioneiro Iterado (DPI). Quatro fontes de feedbacks foram identificadas: apresentados por pares, consumidores, feedbacks de mercado e culturais. Feedbacks de pares e consumidores foram considerados intrínsecos ao DPI, uma vez que não foram manipulados, mas analisados. Feedbacks de mercado e culturais abrangeram variáveis independentes e seus efeitos foram medidos a partir da cooperação entre os jogadores e grupos (variáveis dependentes). Vinte e sete participantes jogaram o DPI, divididos em 9 grupos com três jogadores cada. Cooperação foi medida como taxas de respostas cooperativas X sobre o total de escolhas, bem como os produtos agregados de cada grupo. No nível molecular (momento a momento), foi observado um efeito significativo intra-grupo do feedback de mercado $F(1,28)=6.50, p=.02, \eta_{\mathrm{p} 2}=.19$. No nível molar, não houve efeito significativo do feedback de mercado, tampouco do feedback cultural. Não foi possível estabelecer uma metacontingência entre a cooperação recorrente nos grupos e consequências contingentes positivas. Os jogadores apresentaram comportamentos de escolha subótimos, buscando maximizar ganhos relativos individuais (desertando) sobre ganhos absolutos em seus grupos (cooperando). Esses resultados são discutidos à luz de como a fonte de feedback pode sustentar a cooperação ou a deserção no DPI e suas implicações nos ambientes organizacionais. Reforçar comportamentos cooperativos pode ser essencial para a manutenção e o desenvolvimento de organizações, uma vez que o feedback informativo sobre o desempenho pode ser insuficiente. Este estudo contribui para a compreensão de escolhas econômicas em grupos, sob a perspectiva de seleção cultural.
\end{abstract}

Palavras-chave: escolha, cooperação, feedback, metacontingência, jogo do dilema do prisioneiro

This study explores the effects of feedback on cooperation in the iterated prisoner's dilemma game (PDG). Four sources of feedback were identified: peer, buyer, market and cultural feedback. Peer and buyer feedback were intrinsic to the PDG, for they were analyzed, but not manipulated. Market and cultural feedback comprised independent variables and their effects were measured on players' and group cooperation (dependent variables). Twenty-seven participants played a PDG, divided in 9 groups of 3 players each. Cooperation was measured as rates of individual players' cooperative $\mathrm{X}$ choices, and as aggregate products within groups. At the molecular (moment-to-moment) level, there was a significant within-subjects main effect of the market feedback $F(1,28)=6.50, p=.02, \eta_{\mathrm{p} 2}=.19$. At the molar level, there was no significant effect of the market feedback, nor of the cultural feedback. It was not possible to establish a metacontingency between recurrent group cooperation and positive contingent group consequences. Players displayed sub-optimal choice behavior, seeking to maximize relative earnings within their group (defecting) over absolute earnings (cooperating). These results are discussed in light of how the source of feedback may sustain cooperation or defection in the PDG, and their implications in organizational settings. Reinforcing cooperative behaviors can be key to the maintenance and development of any organization, for informative performance feedback may not suffice. This study contributes to the understanding of economic decisional behavior in groups from a cultural selectionist perspective.

Keywords: choice, cooperation, feedback, metacontingency, prisoner's dilemma game

\footnotetext{
This work has been financially supported by OsloMet - Oslo Metropolitan University. The first author's research exchange in Milan, Italy, was funded by an Erasmus+ staff mobility grant. Thanks to Are Hugo Pripp for his help with the statistical analysis and reporting; Nicholas J. Bergin and Kalliu Carvalho Couto for their exceptional feedback on an earlier draft of this manuscript; Flora Lorenzo for her translation to Portuguese, and to Aécio Borba and the anonymous reviewers for their constructive comments.

Correspondence to: Marco Tagliabue, marco.tagliabue@ oslomet.no

DOI: http://dx.doi.org/10.18542/rebac.v15i1.8671
} 
Several scientific approaches and fields of study have addressed the complex social phenomenon of cooperation. It is a fundamental topic, ranging from how genes interact to the evolution of financial markets. Like competition and exchange, cooperation is an elementary type of social behavior for its ubiquity and importance in social life (Schmitt, 1998). According to Keller and Schoenfeld (1950), for cooperation to occur, "the combined behavior of two or more organisms is needed to procure positive, or remove negative, reinforcement for either" (p. 353, italics in original). The general definition of cooperation implies gaining advantages for all parties involved. Cooperation depends on the concurrent behavior of at least two organisms, who eventually share a common consequence (Brayko, Houmanfar, \& Ghezzi, 2016). From an experimental approach to the analysis of behavior, Schmitt (1998) stated that under a cooperative contingency “....all participants receive a reinforcer if their responses collectively meet a specified performance criterion" ( $p$. 471).

This study assumes a cultural perspective on cooperation, focusing on the interplay of multiple agents' choice behavior. Choice refers to selecting one alternative or course of action and forgoing another (Martin, Yu, Martin, \& Fazzio, 2006). Within a social episode, choice behavior means response allocation, which may assume (mutually) reinforcing value in relation to another person or a group. Experimental studies of choice in behavior analysis inform "both (1) how preferences develop, under different schedules of reinforcement, and (2) how existing preferences influence learning" (Rachlin, 1976, p. 545).

The prisoner's dilemma game (PDG) is a widely adopted experimental setting for studying and measuring cooperation. Introduced in 1950 by RAND consultants Flood and Dresher as an intellectual riddle, it depicts a "precise mathematical construct and also a real-life problem" (Poundstone, 1992, p. 8). The two-player PDG is based on avoiding loss, since betrayal or defection gives the first defector an advantage over the other player. This is also the decision rule programmed by the minimax theorem (Von Neumann, 1928, who founded the field of game theory as a mathematical discipline [Kuhn \& Tucker, 1958]), which minimizes loss in worstcase scenarios. However, if both players cooperate, loss is avoided altogether. This variant was later replaced with a situation in which monetary earnings were introduced after each encounter. Mutual cooperation resulted in second highest payoffs for both players; defection of one player granted the highest payoff if the opponent cooperated, thus, earning the least; mutual defection resulted in the third highest payoff for both players (i.e., less than mutual cooperation, and more than cooperation if the opponent defected). As a result, both players suffer greater losses, despite making the most rational choice for themselves, than if their behavior had been cooperative. Interpreted in terms of self-control, "cooperation benefits the group but is costly to the individual (relative to defection), yet a significant number of players choose to cooperate" (Locey, Safin, \& Rachlin, 2013, p. 85).

The iterated (or repeated) PDG is considered a more versatile version than the original "one-shot" PDG, for it adds a temporal dimension to the study of strategic interactions between players over time. Moreover, it meets the requirement of recurrent behavior, which is one of the two conditions (the other condition being a selecting environmental consequence) for the establishment of a metacontingency (see Delgado, 2012). The main differences between the iterated PDG and the one-time PDG are (a) the players' payoffs, which are converted from number of sentenced years to prison (loss-framed) to monetary gains, and (b) the repetition of the same choicetask over a period of finite rounds.

The PDG is an elective scenario for addressing the boundaries of Homo economicus, which is adopted as an anti-model by subscribers to the behavioral economics paradigm (e.g., Henrich et al., 2001; Yamagishi, Li, Takagishi, Matsumoto, \& Kiyonari, 2014). The dilemma lies in the ambiguity embodied in the game setting: namely, the most beneficial outcomes for the (self-serving) individual do not reflect the most beneficial outcomes for the (prosociality of the) group. These opposed choice behaviors have been previously addressed as forms of free riding and collusion, respectively (Cunningham, 1967). Although each player's choice needs be considered in relation to any other players' choice, for the aims of this study we refer to the convention of interpreting defection (or free riding) as the behavior of choosing $\mathrm{Y}$, and cooperation (or collusion) as the behavior of choosing $\mathrm{X}$ (cf. Rachlin \& Locey, 2011; Yi \& Rachlin, 2004). Previous research has showed how the PDG can be effectively adopted to study constructs such as fairness, altruism and cooperation at large (e.g., Axelrod \& Hamilton, 1981; Falk \& Fischbacher, 2006; Fehr \& Schmidt, 1999; Locey, Jones, \& Rachlin, 2011; Marwell \& Schmitt, 1972; Poundstone, 1992; Rachlin, 2002).

Support for the idea that cooperation is a learned and transmitted cultural practice (Couto, 2018) derives from instances of an ecological PDG, namely in the literature of evolutionary biology and social anthropology (Wilson, 2015). Some species of felines are highly efficient in hunting large prey in the savannah thanks to a set of acquired collective behaviors and signals (e.g., Kozlowski, 2012). Some primates develop shared cultural practices for better adapting to hostile environments, improving their hygiene, and improving the taste of their food by means of washing sweet potatoes (Amaratunga \& Baldry, 2002; Bell, Koranyi, Buchner, \& Rothermund, 2017; Soutschek, Sauter, \& Schubert, 2015). Tomasello and Vaish (2013) addressed cooperation in preverbal humankind, arguing for the emergence and development of altruism and morality (see also Axelrod, 1984, 1986; Ruse, 2012).

In analytical game theory, a Nash equilibrium is a proposed solution to a game according to which no player can improve their outcome by unilaterally changing their strategy (Nash, 1951). This applies to all non-cooperative games featuring a finite number of periods (see also Holth \& Roth, 2004; Myerson, 1978). In one-time games, 
defection usually leads to the highest payoffs, whereas in iterated games, strategies are likely to develop (Norman \& Wallace, 2011). Similarly, whereas defection (Y) represents the most profitable choice and strategy for every single player in the PDG, cooperation (X) grants the highest cumulative payoffs for the group. If players are not permitted to communicate and their choices are displayed simultaneously (cf. sequentially; see Clark \& Sefton, 2001), the experiment does not feature a manifest coordination of strategies. Conversely, iterated games address how coordinated choice may be established and sustained over time. This process may be termed as learning and is affected by the availability and delivery of feedback.

Feedback is an imprecise, non-technical concept in the behavior analytic literature. Broadly defined, feedback refers to both verbal and non-verbal responses (i.e., information), aimed at adjusting performance in a desired or optimal fashion. However, information alone may not suffice to initiate (let alone sustain) behavior change. If feedback contains an assessment of performance, it serves as a consequence of that behavior. In organizational behavior management, performance feedback equals information about past performance (Alvero, Bucklin, \& Austin, 2001), and whether feedback has a reinforcing or punishing effect is an empirical question.

Feedback can be defined as "information about the gap between the actual level and the reference level of a system parameter which is used to alter the gap in some way" (Ramaprasad, 1983, p. 4). Steve Draper (2005) distinguished between the technical notion of feedback, defined as "extra information an entity gets (only) as a result of its acting" (p. 2) and its sharing modalities through discussion and interaction, which are embodied in the process of feedback delivery. Fishbach, Eyal and Finkelstein (2010) explored the signaling and informative effects of receiving and delivering feedback on individuals' goal pursuit and commitment, such as maximizing one's earnings in the PDG. In performance management, delivering feedback tends to take the form of a specific consequence contingent on the agent's behavior (e.g., praising the sale of a stock that reaches its highest market value, or withholding a bonus for failing to meet a project deadline). According to Daniels and Daniels (2004), feedback works best when it reliably signals that positive reinforcement will follow the appropriate behavior. We speak of reinforcement only if the likelihood that a response will occur increases. Feedback equals reinforcement only when it increases the probability of similar behavior in the future. When feedback signals the presentation of a reinforcer, it may acquire the function of a discriminative stimulus, signaling that if a given response class is emitted, there is a probability that certain consequences may follow. The actual consequence may reinforce the behavior that produced it, as a function of previous learning (see Catania, 2007).

Throughout this study, we refer to feedback as verbal and non-verbal consequent stimulation that is both contingent on particular aspects of the behavior and that exerts control over directional changes in future behavior.
Feedback is often provided with the assumption that it will affect future performance; however, it does not on several occasions. In a PDG, the consequences of each player's behavior assume relative significance, as they are normatively established by the purpose and rules of the game. Hence, feedback affects cooperation or defection, if it describes the function of learning or adaptation to a new choice behavior. It denotes a precise and technical relationship, which may strengthen or weaken the occurrence of future similar choices depending on its contingencies of reinforcement, insofar as feedback is inserted within a three-term contingency model.

Behavioral game theory addresses instances of social interaction and how the feedback of one agent's choice influences another agent's choice. It is a descriptively more adequate alternative to the field of analytical game theory, which "concerns the behaviour of decision makers whose decisions affect each other" (Aumann, 2008, p. 1; see also Poundstone, 1992). Although the origins and most extensive adoptions of game theory may be traced to the field of experimental economics (e.g., Embrey, Fréchette, \& Yuksel, 2015; Rubinstein, 1986), because of its flexibility of adaptation and translational implications, the PDG has been exported to the social sciences (Colman, 2013; Ostrom, 2000), neurobiology (Bell et al., 2017; Soutschek et al., 2015), and behavior analysis. Fidelis and Faleiros (2017) engaged in a systematic review of the use of the PDG in the experimental analysis of behavior and found 23 applications of the game, which represented only $7 \%$ of their search results of applications of the PDG. The authors identified an increase and continuity of applications of the PDG published in scientific journals, specifically on the manipulation of social relations and self-control. However, only three experiments adopted the PDG and contained an analysis of metacontingencies (Costa, Nogueira, \& Vasconcelos, 2012; Morford \& Cihon, 2013; Ortu, Becker, Woelz, \& Glenn, 2012).

The metacontingency (Glenn, 1986, 1988, 1991) is a conceptual tool (Todorov, 2006) that describes a functional relationship between (a) interdependent and mutually reinforcing individual choices interlocking behavioral contingencies - IBCs), (b) which produce an aggregate product (AP), and (c) their selecting environment (Glenn et al., 2016). In the PDG, metacontingencies include (a) the players' choices to cooperate or defect, (b) the cumulative choices and relative payoff of the group, and (c) the positive contingent group consequence (i.e., market feedback). The AP is treated as the result of players' IBCs, which taken together comprise a culturant, and the contingent group consequence delivered on fulfilling the criterion of cooperating (see Figure 1). Since the game is iterated, the attractiveness of receiving a contingent group consequence (i.e., bonus points, equally divided among each player) is expected to affect subsequent rounds of the game, once the contingency has been established. This represents a carry-over effect: the increase in likelihood of meeting the requirements for achieving both individual and collective gain from the cooperative choice. 


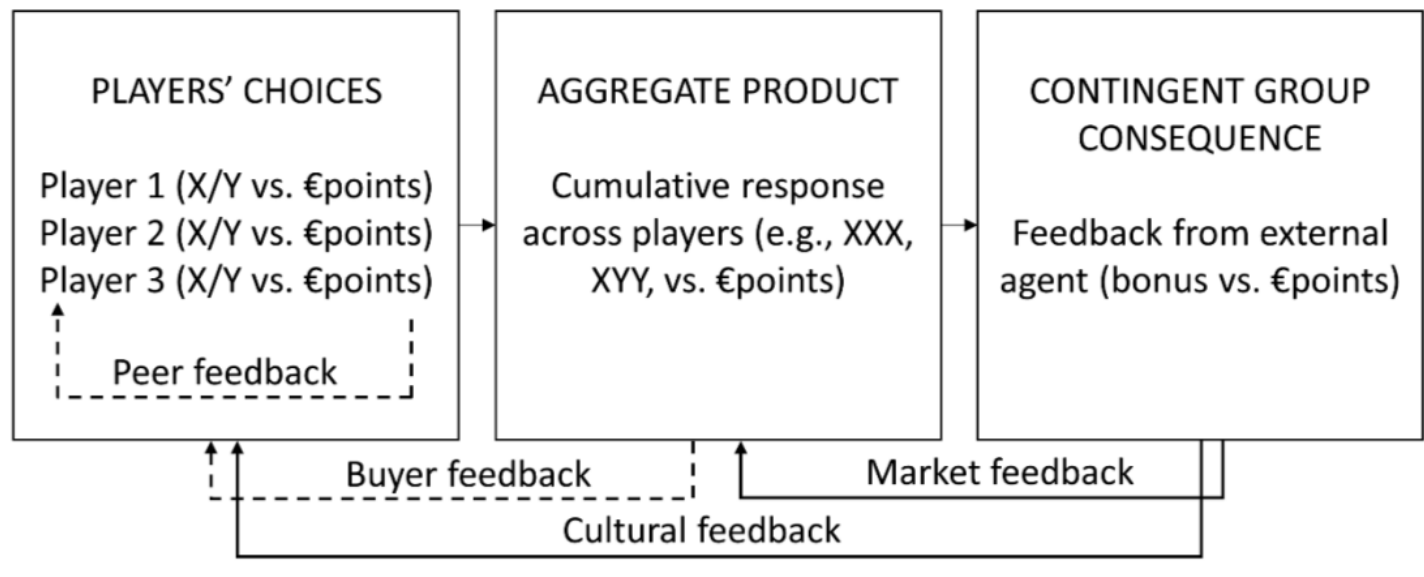

\section{Repeated for $\mathbf{N}$ rounds}

Figure 1. Metacontingency and feedback loops concerning players' decisional relationship towards one another in the prisoner's dilemma game.

Note. The lines represent feedback loops. In this study, dashed lines are analyzed but were not manipulated; solid lines were manipulated. The outline shows interdependent operant consequences for individual player choices and contingent group consequence on the aggregate product. During each round, the players choose X or Y and earn points. In addition, a contingent group consequence in the form of money earned by the company is delivered as market feedback. The value of the market feedback is contingent on the aggregate product that has been produced by the three players (Adapted from Ortu et al., 2012, p. 114.

Examples of metacontingencies in organizational settings have been discussed since the beginning of the 2000s (Malott, 2003; see also Glenn \& Malott, 2004; Houmanfar \& Rodrigues, 2006; Malott \& Glenn, 2006), and to a lesser extent in organizational behavior management (e.g., Biglan, 2009; Sandaker, 2009). Organizations depend on cooperation between their members for their objectives to be achieved, and in order to meet the selection criteria of the consumers (i.e., survive in the market). Thus, complexity characterizes possibly several organizations within a system, which may be embedded within a closed market. Fostering cooperative choices requires a multidimensional understanding of how to best regulate individual and group behavior. Supported by the findings from previous studies, the PDG provides both a suitable and reliable interdisciplinary setup for experimental control of the contingencies that sustain coordinated behavior in groups, and some of the procedural elements of the metacontingency.

In one of the studies identified by Fidelis and Faleiros (2017), a PDG was used to establish a metacontingency of cooperation among four simultaneous players. The effects of the metacontingency persisted even though individual earnings were minimal compared to group earnings (Ortu et al., 2012). In a second study, the authors explored the effects of a metacontingency and verbal behavior (i.e., consensus) in the coordination of choice behavior (Costa et al., 2012). In addition to introducing a metacontingency, a third study featured the option to fine defectors from the common good and found that fining behavior did not affect players' cooperation (Morford \& Cihon, 2013).

The objectives of this study are twofold. First, we study players' choice behavior in the PDG to test whether rates of cooperation may be affected by altering the source of feedback. We introduce the PDG and discuss how it may contribute to the study of cultural phenomena with minor adjustments. Next, we discuss how the source of feedback may sustain cooperation or defection in the PDG. The experiment explores the effects of two manipulated feedback sources on individual choice behavior and group cooperation: they are presented as instances of molecular and molar paradigms (Baum, 2004) of choice.

Second, this study investigates whether a metacontingency may be established between players' cooperative choices and a contingent group consequence. This consequence is positive for both the individual and the group (i.e., is sustainable) and, within the PDG setting, comprises a bonus apt to eliminate the differential individual and group payoffs concurrently embedded in the dilemma. Hence, a cooperative cultural practice may be established, which grants the highest earnings and represents the optimal choice. The experimental findings are discussed in the underlying cultural selectionist perspective, and we conclude with some remarks on the experimental setting and its applied implications.

\section{METHOD}

\section{Participants, Setting and Materials}

Twenty-seven adult participants were divided into 9 groups of 3 players each. Fifteen of them (ages 20 
to 22,10 female) were recruited from a university in Milan, Italy. They signed up on a voluntary basis, as part of their practical assignments within an undergraduate course in management in retail and fashion. The remaining 12 participants (ages 21 to 41,8 female) were recruited from a university in Oslo, Norway. They were approached during their classes in health and social science, and through fliers posted on campus. The participants were invited into a dedicated room on the premises of their respective university campuses, either in Milan or Oslo. Between-group differences across locations were kept to a minimum, for example by using only English language throughout the experimental progress.

The experiments took place in a conference room on the premises of the two universities. The following materials were used: a laptop computer with a Windows $₫ 10$ operating system, a digital projector, a projector screen, and 3 sets of two A5 laminated cards displaying respectively the letter $\mathrm{X}$ and $\mathrm{Y}$ in large print.

\section{Ethics Statement}

Participants were treated in accordance with ethical standards of APA. All procedures performed in studies involving human participants were in accordance with the ethical standards and with the 1964 Helsinki Declaration and its later amendments or comparable ethical standards. Informed consent was obtained from all individual participants included in the study. This study was approved by the Norwegian Social Science Data Service (NSD), n.45638 on November 12, 2015.

\section{Procedure}

The PDG can be modified in a number of ways to study cooperation and defection in dyads or larger groups (Poundstone, 1992). In order to expand on simple behavior-consequence dynamics based on the sums of payoffs and set the occasion for discriminating between self- and group interests, the PDG herein adopted featured some modifications. First, we used a payoff matrix that encouraged cooperative behaviors $(\mathrm{X})$, with a narrower payoff gap between cooperation and free riding, increasing the likelihood of cooperation (Camerer \& Thaler, 2003).

Similar to other n-players iterated PDGs, the traditional dyad setting was expanded to include three simultaneous players to better account for the complexity of a closed market scenario, which resulted in the matrix shown in Table 1. The coordinated behavior of three players helps overcome the shortages in response patterns of dyads (from four to eight possible outputs) while avoiding defection to "almost dominate" over cooperation as $\mathrm{n}$ increases (Kuhn, 2019). Conversely, larger experimental groups enhance the development of a "cooperative agreement", rather than cooperation itself (Bixenstine, Levitt, \& Wilson, 1966, p. 494). Third, we introduced a metacontingency representing a functional relationship between the coordinated (choice) behavior of group members and a selecting consequence.

Table 1

Payoff matrix for a revised 3-players prisoner's dilemma game

\begin{tabular}{lcc}
\hline $\begin{array}{l}\text { Manufacturers } \\
\text { produce }\end{array}$ & $\begin{array}{c}\text { Product X } \\
\text { (€points) }\end{array}$ & $\begin{array}{c}\text { Product Y } \\
\text { (€points) }\end{array}$ \\
\hline $3 \mathrm{X} / 0 \mathrm{Y}$ & +8 & - \\
$2 \mathrm{X} / 1 \mathrm{Y}$ & +3 & +10 \\
$1 \mathrm{X} / 2 \mathrm{Y}$ & +10 & +3 \\
$0 \mathrm{X} / 3 \mathrm{Y}$ & - & +1 \\
\hline
\end{tabular}

Before the experiment began, the participants read and signed an informed consent letter. Next, the instructions (available as supplementary material) were presented on a separate sheet and read in plenary. Each participant was comfortably seated at a rectangular table and facing a wide screen, on which the experimenter projected a scoreboard designed in Excel ${ }_{\circledast}$, illustrated in Figure 2(a). A nametag specifying the players' number (Player 1, 2, or 3) was placed on the table in correspondence to their seat. Seats were not preassigned, nor noteworthy for the game conduct. Thus, the players were able to assign each choice (projected on the screen) to its enactor (seated at the table), without disclosing any of the participants' real name; they could look at, but not talk to one another. The participants were instructed to see themselves in the role of co-owners of a manufacturing company. Their task was to maximize revenue, which depended on both their individual choices and the choices of the other players.

At the beginning of each round, each player chose between two alternatives. Similarly, to previous studies featuring the PDG with metacontingencies, these were X and Y (Morford \& Cihon, 2013; Ortu et al., 2012), which represented two hypothetical and arbitrary products that they could sell to the experimenter, the only buyer in the closed market. Since no vocal communication was permitted, the participants displayed their choices to the experimenter by simultaneously raising the card corresponding to their product of choice. The lack of vocal and written topographies highlights the importance of (a) contingency-specifying stimuli, thus generating rules; and (b) the vocal and written topographies insofar as participants are able to emit duplics (see Michael, 1982), which permitted bypassing the shaping process and quickly displaying a high rate of cooperation (Anonymous, personal communication, November 22, 2019). The experimenter manually recorded the players' choices in the first three columns of the scoreboard and assigned the respective payoff to each player according to the payoff matrix in the following three columns. Whenever the target $3 \mathrm{X}$ AP was met, the market feedback was added in the relevant column: this was verbally emphasized by the experimenter, who called "Bonus!". 


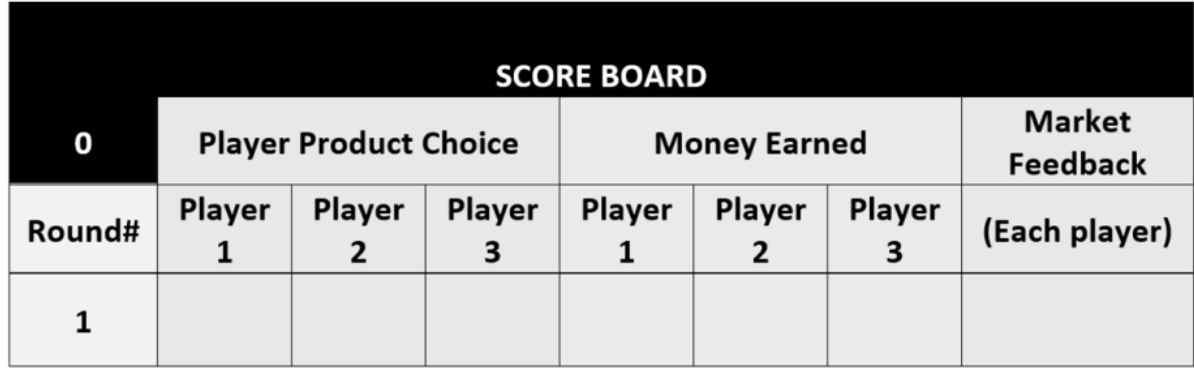

(a)

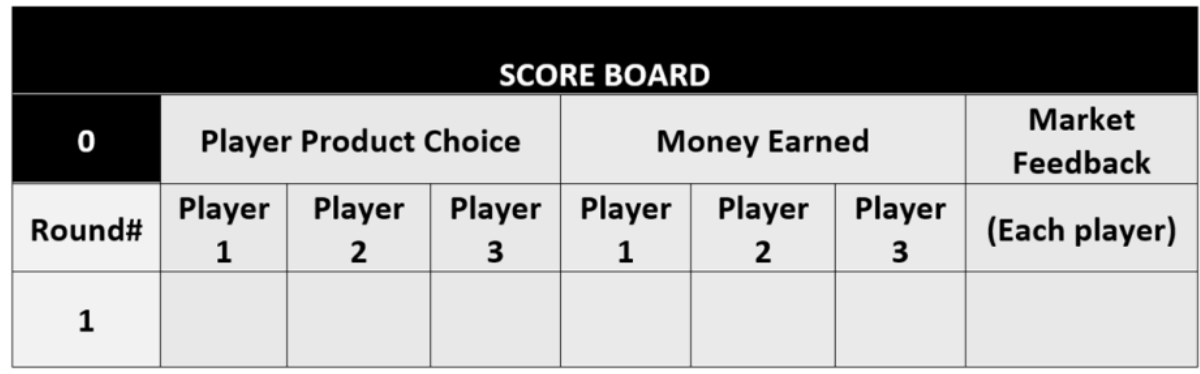

\begin{tabular}{|l|l|}
\hline $\begin{array}{l}\text { Player 1's } \\
\text { Earnings = }\end{array}$ & $€ 0$ \\
\hline $\begin{array}{l}\text { Player 2's } \\
\text { Earnings = }\end{array}$ & $€ 0$ \\
\hline $\begin{array}{l}\text { Player 3's } \\
\text { Earnings = }\end{array}$ & $€ 0$ \\
\hline $\begin{array}{l}\text { Group } \\
\text { Earnings = }\end{array}$ & $€ 0$ \\
\hline
\end{tabular}

(b)

Figure 2. Excel® scoreboard grid without (a) and with (b) exposure to the cultural feedback: the latter includes an additional matrix displaying both players' and group earnings.

The end of the game was announced after 150 rounds, which occurred on average 23 minutes after the start of the session ( $\mathrm{Mdn}=20.26$ minutes). Subsequently, the experimenter provided a short debriefing session, explaining the objectives and the optimal choice strategies of the experiment and any remaining questions from the participants were answered.

Four sources of feedback that might exert control on the players' choice behavior throughout the PDG were identified: (a) peer feedback, (b) buyer feedback, (c) market feedback, and (d) cultural feedback. Peer feedback is each player's verbal and non-verbal reactions to the other players' choice behavior. Buyer feedback is the players' payoffs, singularly or collectively taken. The delivery of a market feedback depends on the AP of the group (i.e., the outcome, given interdependency). This is usually termed cultural consequence and it features a bonus contingent on the presentation of a target buyer feedback (i.e., 3X). Finally, cultural feedback refers to the self-monitoring information of each player's and the group earnings, which is different from how the term cultural consequence in used in the metacontingency literature (e.g., Glenn et al., 2016; see also Hunter, 2012). Hence, two concurrent schedules of reinforcement set the occasion for cooperation and defection, granting different payoffs.

This PDG was programmed for two manipulations of feedback sources. During the first 39 rounds, market feedback was withheld, serving as a control condition (no-MF - market feedback). However, conservative conditions for stability criteria (i.e., "when no systematic increasing or decreasing trends are observed in some measured aspect of [choice] behavior" (Costa \& Cançado, 2012, p. 63) of ten or more cooperative choices were not satisfied in any of the groups, for each player's behavior featured relatively high variation (Salkind, 2010; see also Miller, 2006). At the start of round 40, each player received a bonus starting at $5 €$ points on a continuous reinforcement schedule of reinforcement (CRF), and contingent on the production of the AP $3 \mathrm{X}$ for during any given round: this comprised a market feedback (MF) condition. Since the participants were not paid based on their earnings, €points are aimed at retaining both the score validity embodied in the iterated PDG and the product sales in the simulated market scenario. Hence, either the group received $15 €$ points or $0 €$ points, since individual $X$ choices were not rewarded whenever at least $1 \mathrm{Y}$ was chosen.

Bonuses were increased by $1 €$ point (up to $9 €$ points) every tenth choice with defection (i.e., not-3X), in order to increase the attractiveness of subsequent reinforcement for cooperative choices. As the scoreboard was populated with the players' choices, the program scrolled automatically downwards and displayed a new entry line. This allowed each player to see the 23 most recent choices regardless of whether the cultural feedback was available or not (i.e., in all conditions). This feedback was automatically updated at the end of each round and remained visible at all times, so each player was able to evaluate their performance in comparison with the other players' and the group performance.

Groups 1-3 (no-CF - cultural feedback) served as control groups, for they were not exposed to the cultural feedback. The cultural feedback allowed each player to have access to their own and the others' previous choices, and their cumulative monetary value, which, in turn, may have assumed a discriminative function. Groups 4-9 (CF) comprised the experimental groups, for they received exposure to the cultural feedback. This consisted of an additional $2 \times 4$-cell matrix displayed in the top right corner of the screen in addition to the aforementioned scoreboard common to all conditions. The scoreboard (and the matrix, if applicable) were visible at all times and showed the cumulative earnings for each player and the group (Figure 2(b)). 


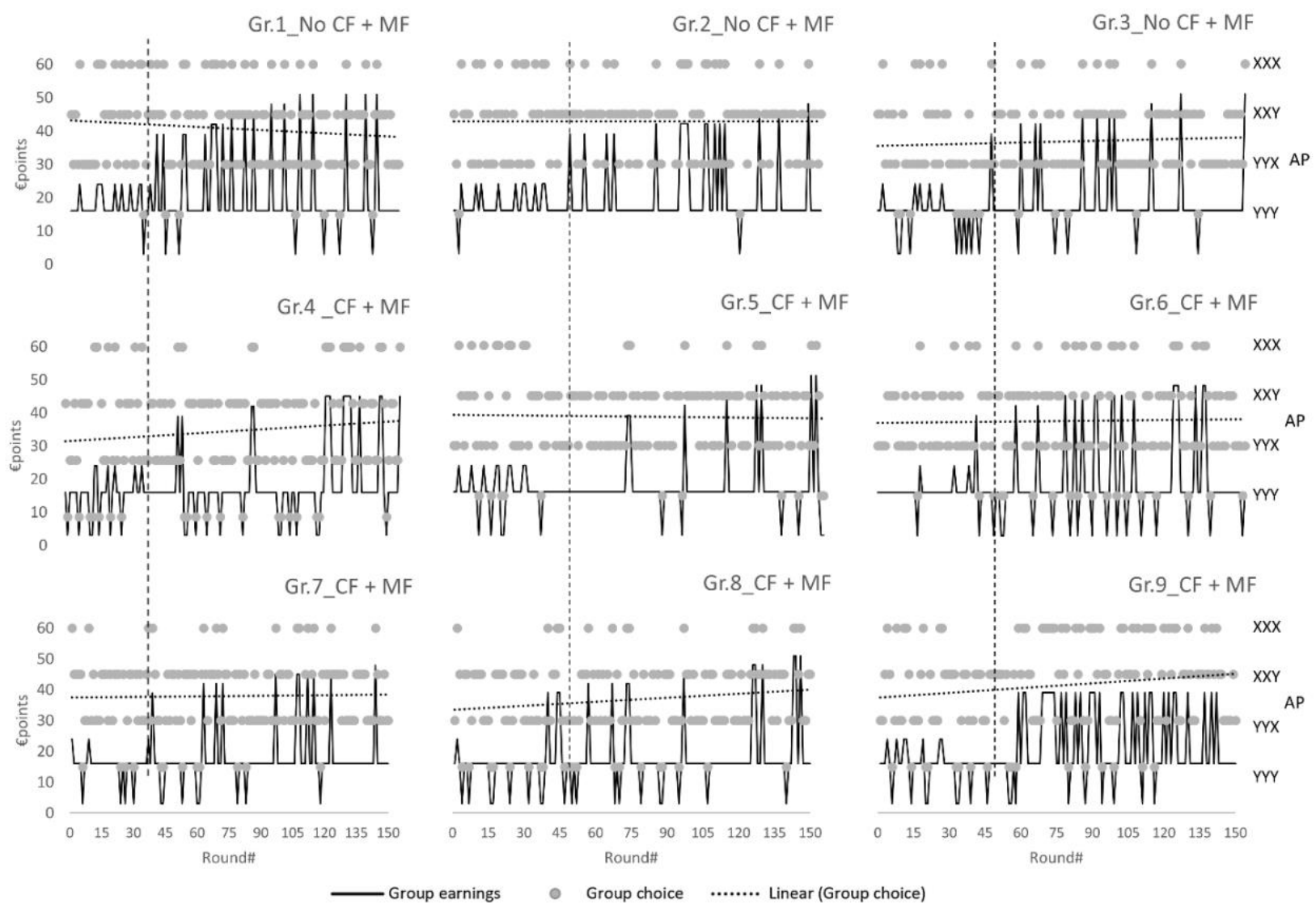

Figure 3. Molecular distribution of group choices (grey dots) and group earnings (black line) for all groups.

Note. All groups were exposed to the market feedback starting from round 40 (MF). Groups 1-3- did not receive exposure to the cultural feedback (No CF); Groups 4-9 were exposed to the cultural feedback (CF). The discontinued dotted line represents the trendline of group choices, measured as aggregate products (plotted as secondary Y values). Dashed vertical lines separate control and experimental market feedback conditions

\section{Dependent experimental variables}

The two primary dependent variables include (a) the players' molecular rates of cooperation (i.e., $\mathrm{X}$ choice), for each round, and (b) the molar rates of cooperation of the group (i.e., AP 3X), clustered in 30 blocks of 5 rounds each (partially based on Yi \& Rachlin, 2004). This configuration of the AP corresponds to a purely cooperative group choice. Secondary measures concerned players' and group earnings, and any group consequence.

\section{RESULTS}

The results are reported based on the relevant dependent experimental variable under analysis: (a) the individual players' choice behavior and (b) the cooperative aggregate product of the group, respectively. Hence, the results include both a molecular and a molar analysis of cooperative choice behavior in the PDG. The data was prepared for analysis using Excel@ for Windows $₫$ and subsequent data analyses and outputs were performed by SPSS Statistics 25®. SPSS outputs of the performed analyses are included as supplementary material. Effects sizes were calculated using Social Science Statistics (2018): they include Cohen's $d$ for independent and repeatedmeasures $t$ tests and Hedges' $g$ (for different sample sizes).

The molecular distribution of cooperative choices (i.e., $\mathrm{X}$ choice) is shown in Figure 3. It displays the aggregate choice (i.e., the AP) for each round and each group. Furthermore, group earnings per round are shown; they comprise the sum of individual payoffs and any awarded bonuses, which account for the highest spikes. From a visual data inspection, it seems that stable rates of cooperation were not achieved in any group. Most group choices feature at least one attempt to defect: for example, Groups 2, 5, and 7 feature flat choice trendlines ranging between one and two players defecting throughout the PDG. Players' choices were generally characterized by a high variability, and the risk of defection (i.e., the fear of receiving the worst individual payoff) was especially high in Groups 4, 6 and 8. From the discontinued lines depicting group choice trends, only 3 groups (Groups 4, 8 and 9) show an increasing trend of cooperative choices, which granted the highest payoff whenever all 3 players chose $\mathrm{X}$ and were awarded a bonus. Whether the increase is due to the experimental manipulation of the market feedback is discussed in the next section. 
Figure 4 displays a molar distribution of cooperative choices, measured as total players' and group earnings for each condition. With the exception of Group 9, which featured a stronger effect of the market feedback compared to all other groups, Groups 1-3 (i.e., no-CF) earned on average more than Groups 4-9 (i.e., CF - Mno_CF
$=€$ points $2806, \mathrm{SD}=188.6 ; \mathrm{MCF}=€$ points $2666, \mathrm{SD}=$ 160.3). However, the means of the groups were not significantly different $t(7)=1.17, p=.28,[g=.83]$ : Table 2 (included as supplementary material) reports the test output.



Figure 4. Number of cooperative responses and number of awarded bonuses, contingent on purely cooperative responses. Note. The principal Y-axis depicts €points on a group earnings scale and the secondary Y-axis depicts €points on individual players' earnings scale. MF refers to market feedback and CF refers to cultural feedback.

\section{Players' Cooperative X Choice}

Analyses were conducted on mean cooperation rates (i.e., $\mathrm{X}$ choices) of the 30 five-round blocks, for each player in each group. Thus, blocks 1-8 represent choices without the market feedback (i.e., no-MF or control), and blocks 9-30 represent choices with the market feedback (i.e., MF or experimental) for all 9 groups. Next, averages were calculated for groups without the cultural feedback (13 ) and with the cultural feedback (Groups 4-9). In contrast to the market feedback, the cultural feedback included information on the both players' and group earnings. Hence, it was not possible to discriminate which type of feedback exerted the strongest control on cooperative behavior, and only ratios of $\mathrm{X}$ choices per block were measured. Ratios were calculated accounting for the occurrence of $X$ choices from any player of each group within a period of 5 consecutive rounds.

A mixed repeated-measures ANOVA was conducted to investigate the impact of cultural and market feedback on the production of individual cooperative choices (i.e., X choice), for each of the 30 blocks. Within subjects, there was a significant main effect of the market feedback $F(1,28)=6.50, p=.02, \eta_{\mathrm{p} 2}=.19$. The interaction effect between market and cultural feedback was not significant, $F(1,28)=0.86, p=.36, \eta_{\mathrm{p} 2}=.03$. Between subjects, there was not a significant effect of the cultural feedback on the players' cooperative choices $F(1,28)=$ 0.53, $p=.48, \eta_{\mathrm{p} 2}=.02$. Table 3 (included as supplementary material) reports within (a) and between (b) effects of the independent variables on cooperative AP of the groups.

In order to further investigate the relationship of the market feedback on cooperative choices, a pairedsamples t-test was performed between means of the groups exposed to the market feedback, plotted in Figure 5(a). A significant effect was found between the means of groups in the first blocks of rounds without the market feedback (no-MF) and the subsequent blocks of rounds with market feedback $(\mathrm{MF}) t(29)=2.40, p=.02, d=.44$ : this effect was moderate and is reported in Table 4 (included as supplementary material). Although the introduction of the market feedback had positive effects on players' cooperative choices, these do not necessarily comprise IBCs, inasmuch as a behavioral contingency term for one player may not functionally precede of follow those of the other players.

\section{Group Cooperative Aggregate Product 3X}

The introduction of the market feedback was hypothesized to positively reinforce cooperative behavior among the members of each group. This was measured as the rate between a fully cooperative AP (i.e., $3 \mathrm{X}$ ) and all possible APs (i.e., 2X1Y, 2Y1X, and 3Y). Cooperation rates were normalized between control and experimental conditions, as market feedback was awarded contingent on AP 3X throughout $36 \%$ of the total PDG duration.

A mixed repeated-measures ANOVA was conducted to investigate the impact of market and cultural feedback on the production of cooperative APs. Within subjects, there was not a significant main effect of the market feedback $F(1,7)=0.68$, 
$p=.44, \eta_{\mathrm{p} 2}=.09$, nor was there a significant interaction between market feedback and cultural feedback $F(1,7)=2.00$, $p=.20, \eta_{\mathrm{p} 2}=.22$. Similarly, between subjects, there was not a significant effect of the cultural feedback on cooperative APs $F(1,7)=1.06, p=.34, \eta_{\mathrm{p} 2}=.13$. Table 5 (included as supplementary material) reports both within (a) and between (b) effects of the independent variables on group cooperative APs.

Post-hoc tests were not performed, as only 2 levels per independent variable were programmed. Nevertheless, as displayed in Figure 5(b), marginal means of groups exposed to the market feedback underwent a decrease concerning the cultural feedback condition. Marginal means of groups that were exposed to the market feedback were similar from without- to with exposure to the cultural feedback. Hence, estimated marginal means resulting from the interaction between market and cultural feedback were tested by performing 2 independent-samples t-tests. However, no significant effect was found between the conditions with cultural feedback and no market feedback, $t(4.11)=1.63, p=$ $.17,[g=1.15]$ (Levene's test indicated unequal variances $(F=$ $.01, p=.90)$, so degrees of freedom were adjusted from 7 to 4.1) and cultural feedback with exposure to the market feedback, $t(7)=-0.94, p=.93,[g=.07]$ (Table 6, included as supplementary material). In sum, these results suggest that group cooperation measured as AP $3 \mathrm{X}$ was highest when participants were least exposed to feedback (or when participants received the least feedback and choice was "freest").



(a)

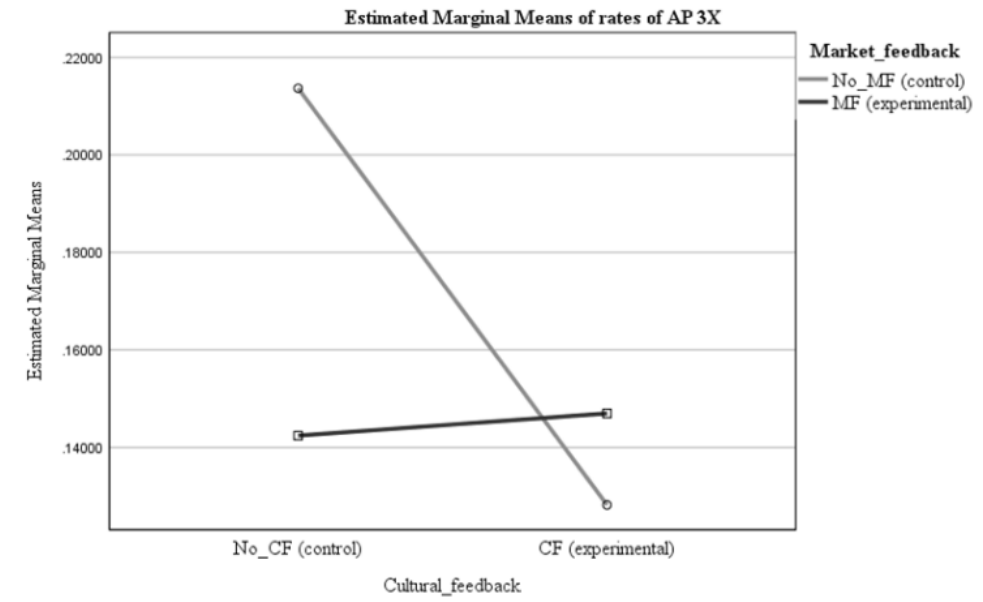

(b)

Figure 5. Estimated marginal means of cooperation, per each control and experimental condition: (a) depicts rates of choice $\mathrm{X}$, and (b) depicts rates of AP $3 \mathrm{X}$.

Note . MF = Market feedback; $\mathrm{CF}=$ Cultural feedback. The grey line marked as No_MF (control) depicts exposure to the market feedback; the black line marked as MF (experimental) depicts exposure to the market feedback. No_CF (control) and $\mathrm{CF}$ (experimental) on the $\mathrm{X}$-axis represent conditions without- and with exposure to the cultural feedback, respectively. 


\section{DISCUSSION}

The PDG experiment included in this study sets the occasion for proposing a cultural selectionist perspective of cooperation in a closed marked scenario. Whenever faced between a choice between $\mathrm{X}$ and $\mathrm{Y}$, each player's behavior was concurrently exposed to the effects of individual and cultural selection. Because bonuses were contingent on the production of the target AP 3X, selection and maintenance of cooperative choices were programmed to override defection. This was the rational strategy for maximizing both players and group earnings. Furthermore, this PDG addressed the role of feedback on establishing and maintaining a cultural practice. Although $\mathrm{X}$ and $\mathrm{Y}$ represented hypothetical products, utilizing the closed market scenario enhances the relevance of the PDG within organizational research. Specifically, differentiating between the functions of reinforcing and informative feedback (e.g., Ramaprasad, 1983) contributes to increasing the technical precision of the terms in the field of organizational behavior and beyond.

In organizational settings, examples of cooperation may include delivery of timely and targeted feedback shared by employees and managers. Feedback can be measured along a number of dimensions, including direction, frequency, quality and timing. Since the second industrial revolution, the literature on performance management suggests that feedback is an exclusive topdown process. In modern organizations, this practice has evolved into a dialogue-oriented dynamic, and subsequently into a network-based exchange of information. There has been an exponential increase in possible nodes and contingencies of interaction between members. This increase includes all directions of delivering feedback to one another: upwards, downwards and horizontally (Amaratunga \& Baldry, 2002; Prue \& Fairbank, 2008).

Although several aspects of the game were directed towards enhancing cooperation (e.g., small number of participants, "conservative" payoff matrix, overt choices, increasing market feedback, etc.), low cooperation rates were initiated and maintained. For example, concerning the number of participants, while the classic two-persons PDG has been extensively used in experiments, there seem to be more contradictory experimental data in settings involving three or more participants, resulting in more individualrewarding rates of responses (Butler, Burbank, \& Chisholm, 2011; Hirshleifer \& Rasmusen, 1989; Marwell \& Schmitt, 1972; Yi \& Rachlin, 2004). Furthermore, the instructions (available as supplementary material) included a nudge towards enhancing participants' cooperation, but the choice of verb cooperate did not seem to affect their choices. This suggests that the participants' behavior was under the control of contingencies of individual and group reinforcement, and not governed by the rule of cooperating included in the instructions. Differently from previous studies (Ortu et al., 2012; Costa et al., 2012), the metacontingency was not regularly established between stable cooperation (i.e., the culturant, seen as recurrent individual cooperative choice behavior and its effect on maximizing group earnings) and the positive contingent group consequence (i.e., the market feedback). This finding is contrasting with the predicted high rates of cooperation embedded in the experimental apparatus.

Nevertheless, this study has several limitations. First, the PDG uses a "pen and paper" procedure, which might be improved by programming dedicated software. Using software allows investigators to retain high levels of standardization, avoid possible biases on the experimenter's side, and exert control on other environmental variables. We also suggest extending the number of rounds played to allow for a more sensible investigation of the establishment and maintenance of metacontingencies. Data from the pilot preceding the experiment indicated that the game duration seemed to be adequate, for it was sufficiently long for observing relatively stable rates of cooperation, yet short enough to be applied in organizational settings without penalizing the workers' productivity. Whether the players were aware of the predetermined game duration did not seem to affect the frequency of their choices and strategies, "even though the famous 'backwards induction' argument would predict so" (Normann \& Wallace, 2011, in Ortu et al., 2012, p. 113). While this variable was not systematically manipulated, the awareness of the total number of trials may have affected the overall rate of defection (e.g., by backward induction; see Aumann, 1995). Nevertheless, stable rates of cooperation were not achieved in any group. Alternatively, the players might be replaced with new ones after a certain number of rounds to investigate the transmission of cultural practices as members interchange (as new-entering members replace old-exiting ones; see Sandaker, 2009).

Third, the participants of this study did not receive any cash payment based on their performance throughout the game. Although cash payments following an experiment represent a common procedure in experimental economics laboratories, other modalities of expressing gratitude for the players' time might not necessarily affect their performance. For example, performance-based payments might be replaced by cash or prize raffles among top ranking players or groups (controlling for within- or between-group competition).

Fourth, there are limitations embedded in the artificial setting of the experiment. Without excluding that some players might have considered the PDG to be similar to a previously experienced closed market scenario, the fact of labeling it as a game might have prompted the players to choose defect over cooperate to a larger extent. The allusion in many cultures to a game setting calls for a winner and, necessarily, at least one loser to emerge. According to Bixenstine et al. (1966), "conceivably, anything construed as a "game" elicits in our culture a very stereotyped, competitive response set" (p. 489).

Finally, in the remainder of this section, we briefly account for the four sources of feedback identified throughout this work. Instances of peer feedback were not formally recorded during the experiment. They may have influenced the players' choices to some extent, although not manifestly so (e.g., rising from their seats as a sign of disappointment) or explicitly uttered. For example, because the players could see one another and their 23 most recent 
choices, it is possible that the availability of cultural feedback was influenced by the fact that groups had access to all players' choices. However, no empirical evidence was collected in support to this claim. In fact, the participants did not engage in any verbal communication with one another, nor with the experimenter. Our findings are consistent with previous work stating that "cooperative gestures toward a non-cooperative partner in the threeperson game had much less chance of eliciting cooperation in return" (Marwell \& Schmitt, 1972, p. 382). Although the main scope of this study was not to explore players' rulegoverned verbal behavior, our findings support the claim that groups in which no vocal communication is allowed engage less in cooperative behavior (Costa et al., 2012; Sampaio et al., 2013), for the selection of culturants is also less consistent (see also Soares et al., 2018)

With regard to the PDG setting, the buyer feedback was supposedly the most influential source of control of the players' choices and, thus, earnings. Namely, it programmed for each player's individual earnings as a function of both their own and the other players' choice. This suggest that a relative earnings-driven strategy (i.e., earning more than the other players) was preferred to a more efficient absolute earnings-driven strategy (i.e., earning the most, regardless of the other players). For example, from a visual inspection of Figure 4, it is clear that all players earned less than what they could have if (a) they consistently defected the other two players in their group ( $\max =1500 €$ points) and (b) if they cooperated unconditionally ( $\max =€$ points $1200+550$ [bonus]). Moreover, average earnings per player $(\mathrm{M}=€$ points 911$)$ and group ( $\mathrm{M}=€$ points 2734) suggest that performance settled at $52 \%$ of capability, which comprises an interestingly mediocre result worthwhile of further experimental and applied investigations.

After the players first acknowledged receipt of a market feedback, whose conditions were not stated in the instructions, no stable pattern of cooperation emerged. This may indicate that: (a) learning did not occur among the players, for group cooperative strategies could not be maintained, or (b) learning may have occurred insofar as a player learned not to cooperate as the others in their group did not cooperate often enough (Anonymous, personal communication, March 4, 2020). In fact, choice $X$ and bonus awarded as many as $12 €$ points, representing the rational (and most lucrative) choice for each player and their group. Although unlikely, the linear increase of bonuses may have been seen as selecting current IBCs that involved defection. The players were informed of how many rounds the game featured, but not of the magnitude and frequency of bonus increases (i.e., assuming they were insensible to temporal and probabilistic discounting). Contrary to this prediction, few cooperative choices were recorded at all, and this finding calls for a cautious approach. In fact, it may be argued that no metacontingency was in effect, since the players were not allowed to engage in overt instances of coordination through verbal behavior (cf. communicate) beyond timid non-verbal efforts to influence each other's subsequent choice that may have occurred. Conversely, IBCs do not necessarily require (verbal) communication for metacontingencies to be established, as demonstrated with animal subjects (de Carvalho et al., 2018) and in the absence of communication (Borba, Tourinho, \& Glenn, 2014; Costa et al., 2012). Nevertheless, it is granted that establishing the metacontingency is harder in the absence of communication, especially when the iterated PDG produces a situation of concurrence between individual and group consequences. Lastly, we recorded that groups exposed to the cultural feedback defected more frequently than groups exposed to the market feedback did. Groups exposed to the cultural feedback may have displayed a lack of adaptability, insofar as the market feedback exerted a stronger control on cooperative choice behavior than the cultural feedback. Alternatively, the chances of cooperation by one player may have decreased assuming that discriminative control presented how often the other players did not cooperate (Anonymous, personal communication, March 4, 2020).

\section{CONCLUSIONS}

The informative function of feedback affects players' cooperative choice behavior in a PDG, insofar as it grants higher earnings for each individual player and not necessarily for their group. Nevertheless, the reinforcing function of feedback did not exert strong control enough on selecting and maintaining a culture of cooperation within groups (i.e., producing the AP 3X). The model of Homo economicus predicts maximizing individual outcomes, which in the setup of this PDG corresponds to maximizing group outcomes. However, players generally seemed to prefer alternate instances of mutual defection to relatively steady cooperation. They displayed irrational choice behavior, putting risky and relative individual gains before sustainable and absolute group gains. Although this statement may be regarded as internalist, insofar as irrational choice may suggest that individuals "reason" in deciding, we maintain that the players responded to the contingencies set in the current and historical context. (Anonymous, personal communication, March 4, 2020).

The study of metacontingencies within a closed market scenario or system consents the understanding of how members of an organization are interdependent. The delivery of common contingent group consequence sets the occasion for putting group interests before individual ones and increasing performance. Thus, metacontingencies are tools of cooperation and not of defection. The stronger the influence of feedback on its contingent choice behavior, the more suitable it is to replace the non-technical concept of feedback with the term reinforcement. Identifying the frames that maintain certain classes of behavior is functional to the maintenance of any organization, market and society. We suggest starting from the design of feedback embedded in these systems, for sustaining cooperation among their members.

\section{DECLARATION OF CONFLICT OF INTEREST}

The authors certify that they have no affiliations with or involvement in any organization or entity with any financial or non-financial in the subject matter or materials discussed in this manuscript. 


\section{CONTRIBUTION OF EACH AUTHOR}

The authors have contributed to all the parts of the manuscript. The first author served as the experimenter.

\section{COPYRIGHT}

This is an open article and may be freely reproduced, distributed, transmitted or modified by anyone provided it is used for non-commercial purposes. The work is made available under the Creative Commons 4.0 BY-NC license.

\section{$(c))$ EY-NC}

\section{REFERENCES}

Alvero, A. M., Bucklin, B. R., \& Austin, J. (2001). An objective review of the effectiveness and essential characteristics of performance feedback in organizational settings (1985-1998). Journal of Organizational Behavior Management, 21(1), 3-29. doi: 10.1300/J075v21n01_02

Amaratunga, D., \& Baldry, D. (2002). Moving from performance measurement to performance management. Facilities, 20(5/6), 217-223. doi: 10.1108/02632770210426701

Aumann, R. J. (1995). Backward induction and common knowledge of rationality. Games and Economic Behavior, 8(1), 6-19. doi: 10.1016/S0899. 8256(05)80015-6

Aumann R. J. (2008). Game theory: Introduction. In S. N. Durlauf, \& L. E. Blume (Eds.), The new Palgrave dictionary of economics (pp. 529-558). London, United Kingdom: Palgrave Macmillan.

Axelrod, R. M. (1984). The evolution of cooperation. New York, NY: Basic Books.

Axelrod, R. M. (1986). An evolutionary approach to norms. American Political Science Review, 80(4), 1095-1111. doi: $10.1017 / \mathrm{s} 0003055400185016$

Axelrod, R. M., \& Hamilton, W. D. (1981). The evolution of cooperation. Science, 211(4489), 1390-1396. doi: 10.1126/science.7466396

Baum, W. M. (2004). Molar and molecular views of choice. Behavioural Processes, 66(3), 349-359. doi: 10.1016/j.beproc.2004.03.013

Bell, R., Koranyi, N., Buchner, A., \& Rothermund, K. (2017). The implicit cognition of reciprocal exchange: automatic retrieval of positive and negative experiences with partners in a prisoner's dilemma game. Cognition and Emotion, 31(4), 657-670. doi: 10.1080/02699931.2016.1147423

Biglan, A. (2009). The role of advocacy organizations in reducing negative externalities. Journal of Organizational Behavior Management, 29(3-4), 215230. doi: 10.1080/01608060903092086

Bixenstine, V. E., Levitt, C. A., \& Wilson, K. V. (1966). Collaboration among six persons in a prisoner's dilemma game. Journal of Conflict Resolution, 10(4), 488-496. doi: 10.1177/002200276601000407

Borba, A., Tourinho, E. Z., \& Glenn, S. S. (2014). Establishing the macrobehavior of ethical self-control in an arrangement of macrocontingencies in two microcultures. Behavior and Social Issues, 23(1), 6886. doi: 10.5210/bsi.v23i0.5354

Brayko, C. A., Houmanfar, R. A., \& Ghezzi, E. L. (2016). Organized cooperation: A behavioral perspective on volunteerism. Behavior and Social Issues, 25, 77-98. doi: 10.5210/bsi.v.25i0.6739

Butler, D. J., Burbank, V. K., \& Chisholm, J. S. (2011). The frames behind the games: Player's perceptions of prisoners dilemma, chicken, dictator, and ultimatum games. The Journal of Socio-Economics, 40(2), 103114. doi: 10.1016/j.socec.2010.12.009

Camerer, C. F., \& Thaler, R. H. (2003). In honor of Matthew Rabin: Winner of the John Bates Clark Medal. The Journal of Economic Perspectives, 17(3), 159-176. http://www.jstor.org/stable/3216827

Catania, A. C. (2007). Learning (4 ed.). Cornwall-onHudson, NY: Sloan.

Clark, K., \& Sefton, M. (2001). The sequential prisoner's dilemma: Evidence on reciprocation. The Economic Journal, 111(468), 51-68. www.jstor.org/stable/2667842

Colman, A. M. (2013). Game theory and its applications in the social and biological sciences. London, United Kingdom: Psychology Press.

Costa, C. E., \& Cançado, C. R. X. (2012). Stability check: a program for calculating the stability of behavior. Mexican Journal of Behavior Analysis, 38, 61-71. doi: v38n1/v38n1a4

Costa, D., Nogueira, C. D. V., \& Vasconcelos, L. A. (2012). Effects of communication and cultural consequences on choices combinations in INPDG with four participants. Revista Latinoamericana de Psicología 44(1), 121-131. http://www.scielo.org.co/

Couto, K. (2018). Selection of cultures and cultural selection: Implications for experimental and applied research (Unpublished doctoral dissertation), OsloMet - Oslo Metropolitan University, Oslo, Norway.

Cunningham, R. (1967). Ethics and Game Theory: The prisoner's dilemma. Papers on Non-Market Decision Making, 2, 11-26. http://www.jstor.org/stable/25066097

Daniels, A. C., \& Daniels, J. E. (2004). Performance management: Changing behavior that drives organizational performance. Atlanta, GA: Performance Management Publications.

de Carvalho, L. C., dos Santos, L., Regaço, A., Barbosa, T. B., da Silva, R. F., de Souza, D. G., \& Sandaker, I. (2018), Cooperative responding in rats maintained by fixed- and variable-ratio schedules. Journal of the Experimental Analysis of Behavior, 110(1), 105-126. doi: $10.1002 /$ jeab.457

Delgado, D. (2012). The selection metaphor: The concepts of metacontingencies and macrocontingencies revisited. Revista Latinoamericana de Psicología, 44(1), 13-24. http://www.scielo.org.co/

Draper, S. (2005). Feedback: A technical memo. Retrieved from http://www.psy.gla.ac.uk/ steve/feedback.html 
Embrey, M., Fréchette, G. R., \& Yuksel, S. (2015). Cooperation in the finitely repeated prisoner's dilemma. SSRN. doi: 10.2139/ssrn.2743269

Falk, A., \& Fischbacher, U. (2006). A theory of reciprocity. Games and Economic Behavior, 54(2), 293-315. doi: 10.1016/j.geb.2005.03.001

Fehr, E., \& Schmidt, K. M. (1999). A theory of fairness, competition, and cooperation. Quarterly Journal of Economics, 114(3), 817-868. doi: 10.1162/003355399556151

Fidelis, D. P., \& Faleiros, P. B. (2017). Prisoner's dilemma in the experimental analysis of behavior: A systematic review. Brazilian Journal of Behavior Analysis, 13(1), 42-52. doi: 10.18542/rebac.v13i1.5262

Fishbach, A., Eyal, T., \& Finkelstein, S. R. (2010). How positive and negative feedback motivate goal pursuit. Social and Personality Psychology Compass, 4(8), 517-530. doi: 10.1111/j.1751-9004.2010.00285.x

Glenn, S. S. (1986). Metacontingencies in Walden Two. Behavior Analysis \& Social Action, 5(1-2), 2-8. doi: 10.1007/BF03406059

Glenn, S. S. (1988). Contingencies and metacontingencies: Toward a synthesis of behavior analysis and cultural materialism. The Behavior Analyst, 11(2), 161-179. doi: 10.1007/BF03392470

Glenn, S. S. (1991). Contingencies and metacontingencies: Relations among cultural, behavioral, and biological evolution. In P. A. Lamal (Ed.), Behavioral analysis of societies and cultural practices (pp. 39-73). Washington, DC: Hemisphere Press.

Glenn, S. S., \& Malott, M. E. (2004). Complexity and selection: Implications for organizational change. Behavior and Social Issues, 13(2), 89-106. doi: 10.5210/bsi.v13i2.378

Glenn, S. S., Malott, M. E., Andery, M. A. P. A., Benvenuti, M. F. L., Houmanfar, R. A., Sandaker, I., . . . Vasconcelos, L. A. (2016). Toward consistent terminology in a behaviorist approach to cultural analysis. Behavior and Social Issues, 25, 11-27. doi: 10.5210/bsi.v.25i0.6634

Henrich, J., Boyd, R., Bowles, S., Camerer, C., Fehr, E., Gintis, H., \& McElreath, R. (2001). In search of Homo economicus: Behavioral experiments in 15 smallscale societies. American Economic Review, 91(2), 73-78. doi: 10.1257/aer.91.2.73

Hirshleifer, D., \& Rasmusen, E. (1989). Cooperation in a repeated prisoners' dilemma with ostracism. Journal of Economic Behavior \& Organization, 12(1), 87-106. doi: 10.1016/0167-2681(89)90078-4

Holth, C. A., \& Roth, A. E. (2004). The Nash equilibrium: A perspective. Proceedings of the National Academy of Sciences, 101(12), 3999-4002. doi: 10.1073/pnas.0308738101

Houmanfar, R. A., \& Rodrigues, N. J. (2006). The metacontingency and the behavioral contingency: Points of contact and departure. Behavior and Social Issues, 15(1), 13-30. doi: 10.5210/bsi.v15i1.342

Hunter, C. S. (2012). Analyzing behavioral and cultural selection contingencies. Revista Latinoamericana de Psicología, 44, 43-54. http://www.scielo.org.co/
Keller, F. S., \& Schoenfeld, W. N. (1950). Principles of psychology. East Norwalk, CT: Appleton-CenturyCrofts.

Kozlowski, S. W. J. (2012). The Oxford handbook of organizational psychology. New York, NY: Oxford University Press.

Kuhn, H. W., \& Tucker, A. W. (1958). John von Neumann's work in the theory of games and mathematical economics. Bulletin of the American Mathematical Society, 64(3), 100-123. doi: 10.1090/s0002-99041958-10209-8

Kuhn, S. (2019). Prisoner's Dilemma. In E. N. Zalta (Ed.) The Stanford encyclopedia of philosophy. https://plato.stanford.edu/archives/sum2019/entries/p risoner-dilemma/

Locey, M. L., Jones, B. A., \& Rachlin, H. (2011). Real and hypothetical rewards. Judgment and decision making, 6(6), 552-564. PMCID: 22582110

Locey, M. L., Safin, V., \& Rachlin, H. (2013). Social discounting and the prisoner's dilemma game. Journal of the Experimental Analysis of Behavior, 99(1), 8597. doi: 10.1002/jeab.3

Malott, M. E. (2003). Paradox of organizational change: Engineering organizations with behavioral systems analysis. Oakland, CA: Context Press.

Malott, M. E., \& Glenn, S. S. (2006). Targets of intervention in cultural and behavioral change. Behavior and Social Issues, 15(1), 31-56. doi: 10.5210/bsi.v15i1.344

Martin, T. L., Yu, C. T., Martin, G. L., \& Fazzio, D. (2006). On choice, preference, and preference for choice. The Behavior Analyst Today, 7(2), 234-241. doi: 10.1037/h0100083

Marwell, G., \& Schmitt, D. R. (1972). Cooperation in a three-person prisoner's dilemma. Journal of Personality and Social Psychology, 21(3), 376-383. doi: $10.1037 / \mathrm{h} 0032319$

Michael, J. (1982). Skinner's elementary verbal relations: Some new categories. The Analysis of Verbal Behavior, 1(1), 1-3. doi: 10.1007/BF03392791

Miller, L. K. (2006). Principles of everyday behavior analysis. Belmont, CA: Thomson/Wardsworth.

Morford, Z. H., \& Cihon, T. M. (2013). Developing an experimental analysis of metacontingencies: Considerations regarding cooperation in a four-person prisoner's dilemma game. Behavior and Social Issues, 22, 5-20. doi: 10.5210/bsi.v22i0.4207

Myerson, R. B. (1978). Refinements of the Nash equilibrium concept. International Journal of Game Theory, 7, 73-80. doi: 10.1007/BF01753236

Nash, J. F. (1951). Non-cooperative games. Annals of Mathematics 54(2), 286- 295. http://www.jstor.org/stable/1969529

Normann, H. \& Wallace, B. (2011). The impact of the termination rule on cooperation in a Prisoner's Dilemma experiment. doi: 10.2139/ssrn.952953

Ortu, D., Becker, A. M., Woelz, T. A. R., \& Glenn, S. S. (2012). An iterated four-player prisoner's dilemma game with an external selecting agent: A metacontingency experiment. Revista 
Latinoamericana de Psicología, 44(1), 111-120. http://www.scielo.org.co/

Ostrom, E. (2000). Collective action and the evolution of social norms. Journal of Economic Perspectives, 14(3), 137-158. doi: 10.1257/jep.14.3.137

Poundstone, W. (1992). Prisoner's dilemma: John von Neuman, game theory, and the puzzle of the bomb. New York, NY: Doubleday.

Prue, D. M., \& Fairbank, J. A. (2008). Performance feedback in organizational behavior management. Journal of Organizational Behavior Management, 3(1), 1-16. doi: 10.1300/J075v03n01_01

Rachlin, H. (1976). Behavior and learning. New York, NY: W. H. Freeman.

Rachlin, H. (2002). Altruism and selfishness. Behavioral and Brain Sciences, 25(2), 239-250. doi: 10.1017/S0140525X02000055

Rachlin, H., \& Locey, M. L. (2011). A behavioral analysis of altruism. Behavioural Processes, 87(1), 25-33. doi: 10.1016/j.beproc.2010.12.004

Ramaprasad, A. (1983). On the definition of feedback. Behavioral Science, 28(1), 4-13. doi: 10.1002/bs.3830280103

Rubinstein, A. (1986). Finite automata play the repeated prisoner's dilemma. Journal of Economic Theory, 39(1), 83-96. doi: 10.1016/0022-0531(86)90021-9

Ruse, M. (2012). The philosophy of human evolution. Cambridge, United Kingdom: Cambridge University Press.

Salkind, N. J. (2010). Encyclopedia of research design (Vol. 1). Thousand Oaks, CA: Sage.

Sampaio, A., Araújo, L., Gonçalo, M., Ferraz, J., Alves Filho, A., Brito, I., Barros, N., \& Calado, J. (2013). Exploring the role of verbal behavior in a new experimental task for the study of metacontingencies. Behavior and Social Issues, 22, 87-101. doi: 10.5210/bsi.v22i0.4180

Sandaker, I. (2009). A selectionist perspective on systemic and behavioral change in organizations. Journal of Organizational Behavior Management, 29(3-4), 276293. doi: 10.1080/01608060903092128

Schmitt, D. R. (1998). Social behavior. In K. A. Lattal \& M. Perone (Eds.), Handbook of research methods in human operant behavior (pp. 471-505). New York, NY: Plenum Press.

Soares, P. F., Rocha, A. P., Guimarães, T. M., Leite, F., Andery, M. A., \& Tourinho, E. (2018). Effects of verbal and non-verbal cultural consequences on culturants. Behavior and Social Issues, 27, 31-46. doi: 10.5210/bsi.v27i0.8252

Social Science Statistics. (2019, July 25). Effect size calculator for t-test. https://www.socscistatistics.com/effectsize/default3.a spx

Soutschek, A., Sauter, M., \& Schubert, T. (2015). The importance of the lateral prefrontal cortex for strategic decision making in the prisoner's dilemma. Cognitive, Affective, \& Behavioral Neuroscience, 15(4), 854860. doi: 10.3758/s13415-015-0372-5
Todorov, J. C. (2006). The metacontingency as a conceptual tool. Behavior and Social Issues, 15(1), 92-94. doi: 10.5210/bsi.v15i1.347

Tomasello, M., \& Vaish, A. (2013). Origins of human cooperation and morality. Annual Review of Psychology, 64(1), 231-255. doi: 10.1146/annurevpsych-113011-143812

Wilson, D. S. (2015). Does altruism exist? Culture, genes, and the welfare of others. New Haven, CT: Yale University Press.

Von Neumann, J. (1928). Zur Theorie der Gesellschaftsspiele [The theory of board games]. Mathematische Annalen, 100, 295-320. In J. Von Neumann, \& O. Morgenstern (1944) Theory of games and economic behavior (pp. 153-155). Princeton, NJ: Princeton University Press.

Yamagishi, T., Li, Y., Takagishi, H., Matsumoto, Y., \& Kiyonari, T. (2014). In search of Homo economicus. Psychological Science, 25(9), 1699-1711. doi: 10.1177/0956797614538065

Yi, R., \& Rachlin, H. (2004). Contingencies of reinforcement in a five-person prisoner's dilemma. Journal of the Experimental Analysis of Behavior, 82(2), 161-176. doi: 10.1901/jeab.2004.82-161

Received: August 08, 2019 Accepted: March 31, 2020 


\section{Instructions}

\section{Supplemental Material}

You are the co-owner of a manufacturing company, together with the other two players, and you cooperate with them in order to sell one of the two products you manufacture, to the one and only buyer, represented by the experimenter.

Your goal is to maximize your earnings, and this depends both on your individual decision and that of each other player.

At the beginning of each round, you are asked to decide whether to sell your product X or Y to the buyer, who is always willing to buy, by simultaneously showing the letter of the product of your choice at the sign of the experimenter. Your machinery can only produce one kind of product per round; therefore you can only choose between X or Y, not both.

During some parts of the game, each of you might have the opportunity of receiving a market feedback, when specific criteria are met: the buyer shall communicate its entity to all players, when applicable.

You are not allowed to communicate with each other throughout the game, nor is any sort of negotiation with the buyer permitted, concerning either quantities or prices. It is in your best interest to formulate an offer, since every sale is associated with a gain, according to the following payoffs:

\begin{tabular}{lll}
\hline Manufacturers' produce & Product X (€points) & Product Y (€points) \\
\hline $3 \mathrm{X} / 0 \mathrm{Y}$ & +8 & - \\
$2 \mathrm{X} / 1 \mathrm{Y}$ & +3 & +10 \\
$1 \mathrm{X} / 2 \mathrm{Y}$ & +10 & +3 \\
$0 \mathrm{X} / 3 \mathrm{Y}$ & - & +1 \\
\hline
\end{tabular}

This game will last exactly 150 rounds and you may keep track of the latest sets of decisions, payoffs and updated real-time scores on the projected screen in front of you at all times.

Are there any questions before we begin?

Bidding is open for round \#1: what will you offer, product $\mathrm{X}$ or $\mathrm{Y}$ ? 
Table 2

Difference of means of group earnings, equal variances assumed

Independent Samples Test

Levene's Test for Equality of Variances

F Sig.

Sig.

$\mathrm{t} \quad \mathrm{df}$

.175

.688

Equal variances assumed

Equal variances not assumed

Note. $d f=$ degrees of freedom. t-test for Equality of Means

\begin{tabular}{cccc}
\multirow{2}{*}{$\begin{array}{c}\text { Mean } \\
\text { Difference }\end{array}$} & \multirow{2}{*}{$\begin{array}{c}\text { Std. Error } \\
\text { Difference }\end{array}$} & \multicolumn{2}{c}{$\begin{array}{c}\text { 95\% Confidence Interval of the } \\
\text { Difference }\end{array}$} \\
\cline { 3 - 4 } & & Lower & Upper \\
\hline 140.500 & 119.426 & -141.899 & 422.899 \\
140.500 & 127.048 & -231.914 & 512.914 \\
\hline
\end{tabular}


Table 3

Mixed repeated-measures ANOVA within (a) and between (b) subjects on individual cooperative choice

Tests of Within-Subjects Effects

\begin{tabular}{|c|c|c|c|c|c|c|c|}
\hline Source & & $\begin{array}{l}\text { Type III Sum of } \\
\text { Squares }\end{array}$ & df & Mean Square & $\mathrm{F}$ & Sig. & Partial Eta Squared \\
\hline \multirow[t]{4}{*}{ Market_feedback } & Sphericity Assumed & .026 & 1 & .026 & 6.502 & .017 & .188 \\
\hline & Greenhouse-Geisser & .026 & 1.000 & .026 & 6.502 & .017 & .188 \\
\hline & Huynh-Feldt & .026 & 1.000 & .026 & 6.502 & .017 & .188 \\
\hline & Lower-bound & .026 & 1.000 & .026 & 6.502 & .017 & .188 \\
\hline \multirow{4}{*}{$\begin{array}{l}\text { Market_feedback* } \\
\text { Cultural_feedback }\end{array}$} & Sphericity Assumed & .003 & 1 & .003 & .861 & .361 & .030 \\
\hline & Greenhouse-Geisser & .003 & 1.000 & .003 & .861 & .361 & .030 \\
\hline & Huynh-Feldt & .003 & 1.000 & .003 & .861 & .361 & .030 \\
\hline & Lower-bound & .003 & 1.000 & .003 & .861 & .361 & .030 \\
\hline \multirow[t]{4}{*}{$\overline{\text { Error(MF) }}$} & Sphericity Assumed & .111 & 28 & .004 & & & \\
\hline & Greenhouse-Geisser & .111 & 28.000 & .004 & & & \\
\hline & Huynh-Feldt & .111 & 28.000 & .004 & & & \\
\hline & Lower-bound & .111 & 28.000 & .004 & & & \\
\hline
\end{tabular}

(a)

Tests of Between-Subjects Effects

\begin{tabular}{|c|c|c|c|c|c|c|}
\hline Source & $\begin{array}{l}\text { Type III Sum of } \\
\text { Squares }\end{array}$ & $\mathrm{df}$ & Mean Square & $\mathrm{F}$ & Sig. & $\begin{array}{l}\text { Partial Eta } \\
\text { Squared }\end{array}$ \\
\hline Intercept & 13.359 & 1 & 13.359 & 2993.583 & .000 & .991 \\
\hline Cultural_feedback & .002 & 1 & .002 & .535 & .470 & .019 \\
\hline Error & .125 & 28 & .004 & & & \\
\hline
\end{tabular}

Error

.125

Note. $d f=$ degrees of freedom. 
Table 4

Difference of means of market feedback on individual cooperative choice

Paired Samples Test

$\underline{\text { Paired Differences }}$

95\% Confidence Interval of the

Difference

\begin{tabular}{|c|c|c|c|c|c|c|c|c|c|}
\hline & & \multirow[b]{2}{*}{ Mean } & \multirow[b]{2}{*}{ Std. Deviation } & \multirow[b]{2}{*}{ Std. Error Mean } & & \multirow[b]{2}{*}{ df } & \multirow{2}{*}{ Sig. (2-tailed) } \\
\hline & & & & & Lower & Upper & $\mathrm{t}$ & & \\
\hline$\overline{\text { Pair } 1}$ & $\begin{array}{l}\text { No-Market_feedback - } \\
\text { Market_feedback }\end{array}$ & .039 & .089 & .016 & .006 & .072 & 2.399 & 29 & .023 \\
\hline
\end{tabular}


Table 5

Mixed repeated-measures ANOVA within (a) and between (b) subjects on cooperative aggregate product

Tests of Within-Subjects Effects

\begin{tabular}{|c|c|c|c|c|c|c|c|}
\hline Source & & $\begin{array}{l}\text { Type III Sum of } \\
\text { Squares }\end{array}$ & df & Mean Square & $\mathrm{F}$ & Sig. & Partial Eta Squared \\
\hline \multirow[t]{4}{*}{ Market_feedback } & Sphericity Assumed & .003 & 1 & .003 & .682 & .436 & .089 \\
\hline & Greenhouse-Geisser & .003 & 1.000 & .003 & .682 & .436 & .089 \\
\hline & Huynh-Feldt & .003 & 1.000 & .003 & .682 & .436 & .089 \\
\hline & Lower-bound & .003 & 1.000 & .003 & .682 & .436 & .089 \\
\hline \multirow{4}{*}{$\begin{array}{l}\text { Market_feedback * } \\
\text { Cultural_feedback }\end{array}$} & Sphericity Assumed & .008 & 1 & .008 & 2.007 & .199 & .223 \\
\hline & Greenhouse-Geisser & .008 & 1.000 & .008 & 2.007 & .199 & .223 \\
\hline & Huynh-Feldt & .008 & 1.000 & .008 & 2.007 & .199 & .223 \\
\hline & Lower-bound & .008 & 1.000 & .008 & 2.007 & .199 & .223 \\
\hline \multirow[t]{4}{*}{ Error(Market_feedback) } & Sphericity Assumed & .028 & 7 & .004 & & & \\
\hline & Greenhouse-Geisser & .028 & 7.000 & .004 & & & \\
\hline & Huynh-Feldt & .028 & 7.000 & .004 & & & \\
\hline & Lower-bound & .028 & 7.000 & .004 & & & \\
\hline
\end{tabular}

(a)

Tests of Between-Subjects Effects

\begin{tabular}{lllllll}
\hline Source & $\begin{array}{l}\text { Type III Sum of } \\
\text { Squares }\end{array}$ & df & Mean Square & F & Sig. & $\begin{array}{l}\text { Partial Eta } \\
\text { Squared }\end{array}$ \\
\hline Intercept & .399 & 1 & .399 & 64.378 & .000 & .902 \\
Cultural_feedback & .007 & 1 & .007 & 1.058 & .338 & .131 \\
Error & .043 & 7 & .006 & & & \\
\hline
\end{tabular}

Error

(b)

Note. $d f=$ degrees of freedom. 
Table 6

Difference of means of market feedback on cooperative aggregate product

Independent Samples Test between market feedback conditions for AP $3 X$

Levene's Test for

$\underline{\text { Equality of Variances } \quad \text { t-test for Equality of Means }}$

95\% Confidence Interval of

Mean Std. Error

the Difference

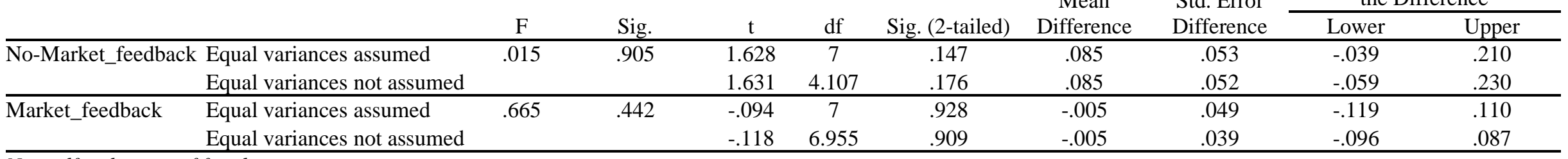

Note. $d f=$ degrees of freedom 